Research Paper

\title{
MicroRNA-34a Inhibits Human Osteosarcoma Prolif- eration by Downregulating Ether à go-go 1 Expression
}

\author{
Xinyu $\mathrm{Wu}^{1^{*}}$, Daixing Zhong ${ }^{2^{*}}$, Quan $\mathrm{GaO}^{3^{*}}$, Wenliang Zhai ${ }^{3}$, Zhenqi Ding 3 , Jin $\mathrm{Wu}^{3 凶}$ \\ 1. Department of Neurology, the Affiliated Southeast Hospital of Xiamen University, Zhangzhou, 363000, China. \\ 2. Department of Thoracic Surgery, the Affiliated Tangdu Hospital of Fourth Military Medical University, Xi'an, 710038, China. \\ 3. Department of Orthopaedics, the Affiliated Southeast Hospital of Xiamen University, Orthopaedic Center of People's Liberation Army, \\ Zhangzhou, 363000, China. \\ * These author contributed equally to this work.
}

$\triangle$ Corresponding author: Dr. Jin Wu, Department of Orthopaedics, the Affiliated Southeast Hospital of Xiamen University, Orthopaedic Center of People's Liberation Army, Zhangzhou, 363000, China. Tel: 86-0596-2931538; Fax: 86-0596-2931538; emails: zhenqiding175th@yahoo.com.cn.

(c) Ivyspring International Publisher. This is an open-access article distributed under the terms of the Creative Commons License (http://creativecommons.org/ licenses/by-nc-nd/3.0/). Reproduction is permitted for personal, noncommercial use, provided that the article is in whole, unmodified, and properly cited.

Received: 2012.11.12; Accepted: 2013.03.21; Published: 2013.04 .03

\begin{abstract}
Aberrant expression of MicroRNAs (miRNAs) has been implicated in several types of cancer. As a direct target gene of $\mathrm{p} 53$, miR-34a has been suggested to mediate the tumor suppressor function of $\mathrm{p} 53$. Ether à go-go I (Eagl) channel is overexpressed in a variety of cancers and plays important roles in cancer progression. However, the link between miR-34a and Eagl in cancer is unclear. In this study, we used human osteosarcoma as the model to demonstrate that miR-34a was significantly downregulated in osteosarcoma tissues and cell lines compared with normal brain tissues and osteoblastic cell line. Next we evaluated the role of miR-34a in the regulation of osteosarcoma cell proliferation by CCK-8 and colony formation assays. The results showed that overexpression of miR-34a inhibited the proliferation of MG-63 and Saos-2 cells. Furthermore, xenograft nude mice model showed that miR-34a inhibited osteosarcoma growth in vivo. Mechanistically, we found that overexpression of miR-34a led to decreased Eagl expression in osteosarcoma cells while inhibition of miR-34a increased Eagl expression. Taken together, our results suggest that miR-34a could inhibit osteosarcoma growth via the down regulation of Eagl expression.
\end{abstract}

Key words: Ether à go-go1 (Eag1); MicroRNA-34a; proliferation; osteosarcoma; target gene.

\section{Introduction}

Osteosarcoma is a primary mesenchymal tumor characterized histologically by malignant tumor cells that directly produce osteoid or immature bone [1]. Osteosarcoma develops in the long bones of the body, such as the femur, the tibia or the humerus in about $80 \%$ patients [2]. Osteosarcoma has high metastatic potential and the main sites of metastases are the lungs, pleura, and the heart [3]. With the improvements in osteosarcoma therapy, 5-year survival rate for osteosarcoma patients without metastatic disease increases to $65 \%$ [4]. However, approximately $40-50 \%$ of patients will develop metastases, especially pulmonary metastases, and few of them could be cured [5]. Therefore, it is urgent to develop new treatment strategies for osteosarcoma in the clinic. Several genetic alterations have been found to be associated with osteosarcoma [6], suggesting the potential application of gene therapy in osteosarcoma treatment. microRNAs (miRNAs) are short, highly conserved small non-coding RNA molecules of about 22 nucleotides in length that regulate gene expression by binding to the $3^{\prime}$ untranslated region $\left(3^{\prime}\right.$-UTR) of the 
complementary mRNA sequence, resulting in translational repression and gene silencing [7-9]. Recently, abnormal expression of miRNAs is found in various human tumors and suggested to be associated with the proliferation, differentiation, apoptosis and invasion of tumor cells, including osteosarcoma [10,11]. Although aberrant expression of several miRNAs such as miR-199a [12], miR-21 [13] and miR-93 [14] have been reported for osteosarcoma, the molecular mechanisms for regulatory processes of miRNAs in osteosarcoma remain largely elusive.

In this study, we found that microRNA-34a (miR-34a) was downregulated in osteosarcoma tissues compared with normal bone tissues. Furthermore, miR-34a could suppress osteosarcoma cell proliferation in vitro and tumor growth in xenograft model of osteosarcoma. Finally, we found that Eag1 was regulated by miR-34a via a negative feed-forward mechanism. In conclusion, we demonstrated that miR-34a may function as a tumor suppressor through downregulating Eag1 expression in osteosarcoma.

\section{Materials and methods}

\section{Cell culture}

Human osteosarcoma cell line MG-63 and Saos-2, and human osteoblastic cell line hFOB 1.19 were purchased from the American Type Culture Collection (ATCC, Rockville, MD, USA). MG-63 and Saos-2 cells were cultured in RPMI-1640 medium (Gibco, Rockville, MD, USA) supplemented with $10 \%$ fetal bovine serum (FBS) (Gibco), $100 \mathrm{IU} / \mathrm{ml}$ penicillin, $100 \mu \mathrm{g} / \mathrm{ml}$ streptomycin in a humidified atmosphere of $5 \% \mathrm{CO}_{2}$ at $37^{\circ} \mathrm{C}$. hFOB 1.19 cells were cultured in ham's F12/ Dulbecco's modified Eagle medium (DMEM) (Gibco) supplemented with $10 \%$ (v/v) FBS, $100 \mathrm{U} / \mathrm{ml}$ penicillin, and $100 \mu \mathrm{g} / \mathrm{ml}$ streptomycin in a humidified atmosphere with $5 \% \quad \mathrm{CO}_{2}$ at $33.5^{\circ} \mathrm{C}$. All cells were subcultured every $3-4$ days.

\section{Tissue samples}

Surgically resected paired 10 osteosarcoma specimens (before the administration of neoadjuvant chemotherapy) and 10 adjacent normal bone tissues were acquired from the affiliated Southeast Hospital of Xiamen University between January 2010 and June 2011. All the specimens were obtained after obtaining written informed consent according to a protocol approved by Institutional Review Board of the affiliated Southeast Hospital of Xiamen University.

\section{Plasmid construction and transfection}

A 264-bp DNA fragment containing pri-miR-34a was amplified by PCR from human genomic DNA using the following primers: pri-34a-sense 5'-CAC AAG CTT TCC TCC CCA CAT TTC CTT C-3', and pri-34a-antisense 5'-CGC TCG AGT CCT GGC GTC TCC CAC TG-3', and subcloned into pcDNA3.1(+) vector (Invitrogen, Rockville, MD, USA) carrying neomycin resistance gene. The recombinant constructs were verified by DNA sequencing. Transfection was performed using Lipofectamine ${ }^{\mathrm{TM}} 2000$ (Invitrogen) according to the manufacturer's instructions.

\section{Polymerase Chain Reaction (PCR)}

Total RNA was isolated from the cultured cells or tissue samples by Trizol reagent (Invitrogen). RNA purity and integrity was checked by running an aliquot on a denaturing $1 \%(\mathrm{w} / \mathrm{v})$ agarose gel. The stem-loop RT (reverse transcription)-PCR was used to measure the miR-34a level as previously described [15]. The small RNA was reverse transcribed to cDNA using $3.33 \mathrm{U} / \mu \mathrm{l}$ MultiScribe reverse transcriptase (Applied Biosystems, CA), plus 1× RT buffer, $0.25 \mathrm{mM}$ each of dNTPs, and $0.25 \mathrm{U} / \mu \mathrm{l}$ RNase inhibitor and the 34a-RT and U6-RT primers (Applied Biosystems). Then the cDNA was used for the amplification of mature miR-34a and an endogenous control U6 snRNA (small nuclear RNA), with the specific forward primers and the universal reverse primers. Each experiment was repeated three times. Some of PCR products were sequenced to check PCR specificity.

\section{Cell proliferation assay}

Cell proliferation was analyzed by using Cell Counting Assay Kit-8 (CCK-8) (Dojindo Molecular Technologies, Gaithersburg, MD) according to the manufacturer's protocol. Briefly, $5 \times 10^{3}$ cells were starved in serum-free medium for $12 \mathrm{~h}$ and then the cells were transfected with plasmids. After 24, 48, 72 and $96 \mathrm{~h}$, the cells were harvested. Ten microliters of CCK-8 solution was added to each well, the cells were incubated for $1 \mathrm{~h}$, and the absorbance (A) at $490 \mathrm{~nm}$ was measured by using the automatic multiwell spectrophotometer (Bio-Rad, Richmond, CA). Experiments were performed at least three times with representative data presented.

\section{Colony formation assay}

For the colony formation assay, $0.5 \%$ agar (Sigma, St. Louis, MO, USA) was added in $60 \mathrm{~mm}$ dishes. The transfected MG-63 or Saos-2 cells were mixed with $0.3 \%$ soft agar and added on the bottom agar with $1 \times 10^{3}$ cells per dish. The cells were incubated for up to 2 weeks. Colonies with more than 50 cells were counted at $14 \mathrm{~d}$ after transfection. 


\section{Tumorigenicity assay in nude mice}

Thymus-null BALB/c nude mice (female, age 4-6 weeks) were obtained from the Animal Center of Chinese Academy of Medical Sciences. All animal procedures were performed according to approved protocols and in accordance with recommendations for the proper use and care of laboratory animals. Osteosarcoma xenografts were established in nude mice as described previously [16]. Briefly, pcDNA3.1 (control group) or miR-34a (miR-34a group) transfected osteosarcoma MG-63 cells $\left(1 \times 10^{5}\right)$ were suspended in $0.1 \mathrm{ml}$ phosphate-buffered saline (PBS) and then injected subcutaneously into the proximal tibia of each anesthetized nude mice ( $\mathrm{n}=6$ in each group). Tumor growth was measured using caliper weekly and tumor volume $\left(\mathrm{cm}^{3}\right)$ was determined with following formula: $a b^{2} / 2$ where $a$ was the length and $b$ was the width of the tumor.

\section{Western blot analysis}

$5 \sim 6 \times 10^{7}$ cells were collected and lysed in ice-cold lysis buffer containing $50 \mathrm{mmol} / \mathrm{L}$ Tris-Cl (pH 7.5), $150 \mathrm{mmol} / \mathrm{L} \mathrm{NaCl}, 0.2 \mathrm{mmol} / \mathrm{L}$ EDTA, 1 $\mathrm{mmol} / \mathrm{L}$ PMSF and 1\% Nonidet-P40 for $30 \mathrm{~min}$. The lysates were centrifuged at $13,200 \mathrm{rpm}$ for $10 \mathrm{~min}$ at $4^{\circ} \mathrm{C}$ and the supernatants were collected. $50 \mu \mathrm{g}$ protein were resolved by $12 \%$ SDS-PAGE and blotted onto nitrocellulose membranes (Bio-Rad). Membranes were blocked with $10 \%$ nonfat milk powder at room temperature for $1 \mathrm{~h}$, then incubated with antibodies to Eag1 (Alomone laboratories, Jerusalem, Israel) and GAPDH (Santa Cruz Biotechnology, CA, USA) overnight at $4^{\circ} \mathrm{C}$, followed by incubation with horseradish peroxidase-conjugated secondary antibody (Santa

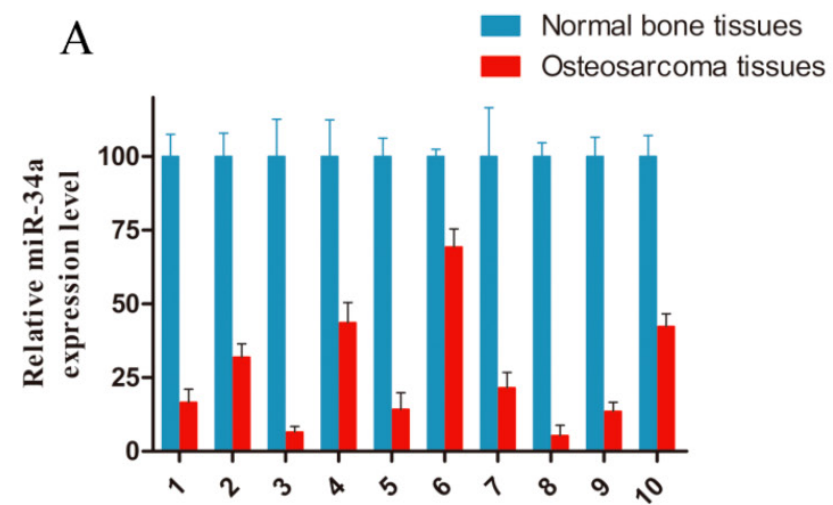

Cruz Biotechnology). Finally, the membranes were developed with chemiluminescent detection kit (Zhongshan Biotechnology, Beijing, China) and exposed to X-ray films. Experiments were performed at least three times with representative data presented.

\section{miR-34a inhibition}

miR-34a was inhibited by miR-34a-2'-O-Methyl antisense oligoribonucleotide (miR-34a-2'-O-Me) as previously described [17]. miR-34a-2'-O-Me was a chemically synthesized, single-stranded, modified RNA which specifically inhibited endogenous miR-34a function after transfection into the cells. Oligos were transfected at a final concentration of $80 \mathrm{nM}$ by using Lipofectamine ${ }^{\mathrm{TM}} 2000$ (Invitrogen) according to manufacturer's instructions.

\section{Statistical analysis}

All data were presented as mean \pm standard error of mean (SEM). Statistical significance was determined using t-test or analysis of variance (ANOVA) using the SPSS18.0 program. $p<0.05$ was considered as statistically significant difference.

\section{Results}

\section{miR-34a is downregulated in osteosarcoma}

To evaluate a possible involvement of miR-34a in osteosarcoma tumorigenesis, we examined its expression level in human osteosarcoma. As shown in Fig. 1, miR-34a was downregulated in ten osteosarcoma tissues (Fig. 1A) and two osteosarcoma cell lines (Fig. 1B), compared with normal bone tissues and osteoblastic cell line. These data are consistent with previous report [18].

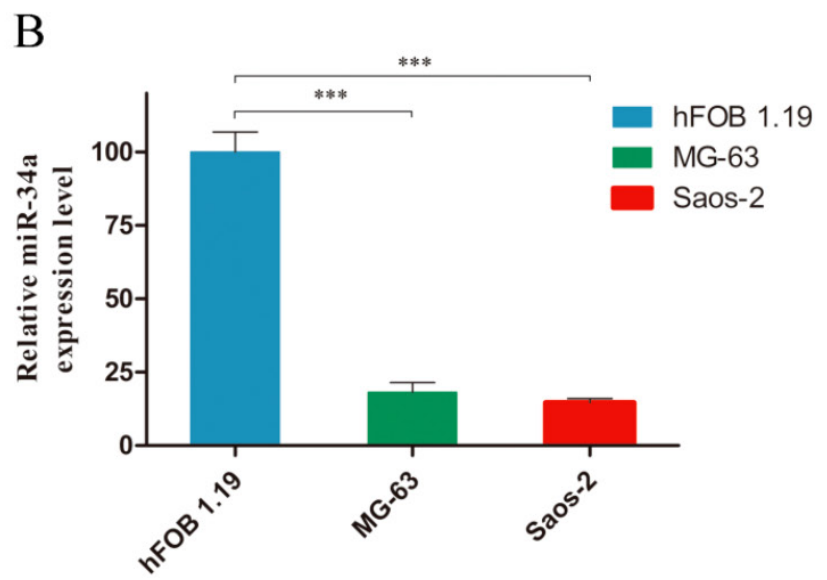

Figure I. miR-34a is downregualted in osteosarcoma tissues and cells. A: The miR-34a expression level was measured in ten pairs of osteosarcoma tissues and normal bone tissues by stem-loop RT-PCR. B: Considerably reduced miR-34a expression was observed in MG-63 and Saos-2 cells, compared to hFOB I.19 cells. The miR-34a level in normal bone tissues and hFOB I.I9 cells was normalized to $100 \%$. *** $P<0.001$. 


\section{miR-34a inhibits osteosarcoma cell prolifera- tion}

To characterize the possible role of miR-34a in osteosarcoma cells, we constructed a pcDNA/miR-34a vector to overexpress miR-34a (Fig. 2). Osteosarcoma cells were transfected with either pcDNA-miR-34a or pcDNA3.1(+) and then selected by G418 treatment for 6 weeks to generate stable MG-63 and Saos-2 cells that overexpress miR-34a. By CCK-8 and colony formation assay, we demonstrated that miR-34a inhibited the proliferation and colony formation of MG-63 and Saos-2 cells (Fig. 3). These results suggest that miR-34a plays a tumor suppressor role in osteosarcoma cells.

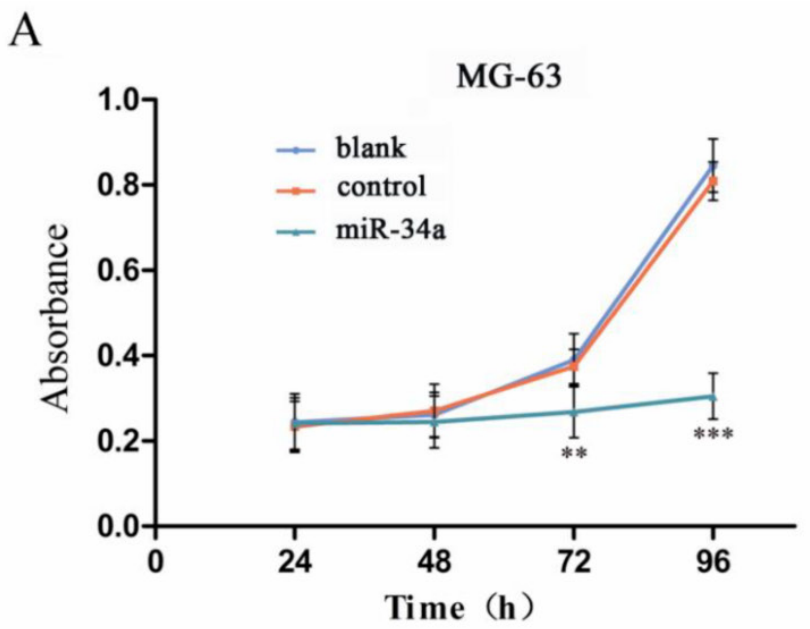

B
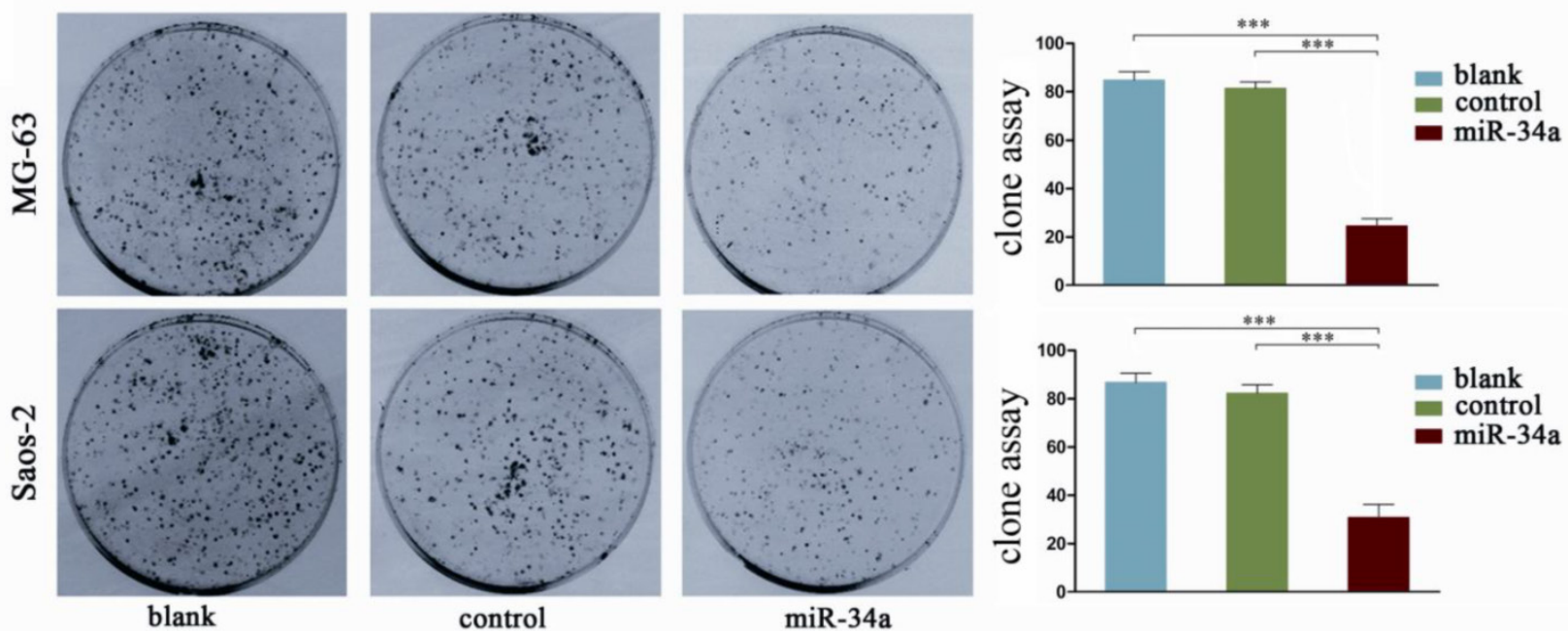

Figure 3. miR-34a inhibits the proliferation of osteosarcoma cells. A: The proliferation of osteosarcoma cells was determined by CCK-8 assay at $24,48,72$, and $96 \mathrm{~h}$ after transfection of miR-34a into MG-63 and Saos-2. The proliferation of osteosarcoma cells was significantly reduced after transfection wtih miR-34a. Data were presented as mean $\pm S D(n=6)$. B: The tumorigenicity of osteosarcoma cells was determined by colony formation assay. The tumorigenicity of osteosarcoma cells was significantly reduced after transfection wtih miR-34a. Data were presented as mean \pm SD $(n=3)$. ** $\mathrm{P}<0.0 \mathrm{I}$, *** $\mathrm{P}<0.00 \mathrm{I}$. 


\section{miR-34a inhibits tumor growth in xenograft model of osteosarcoma}

To investigate the in vivo role of miR-34a in osteosarcoma, we established a xenograft model of osteosarcoma in nude mice. The results showed that the tumor volume was significantly smaller in control group compared to miR-34a group (Fig. 4). These in vivo data confirm our in vitro results and suggest that miR-34a functions as a tumor suppressor in osteosarcoma.

\section{miR-34a regulates Eag I expression in osteo- sarcoma}

Eag1 has been shown to function as an oncogene, and we reported previously that knockdown of Eag1

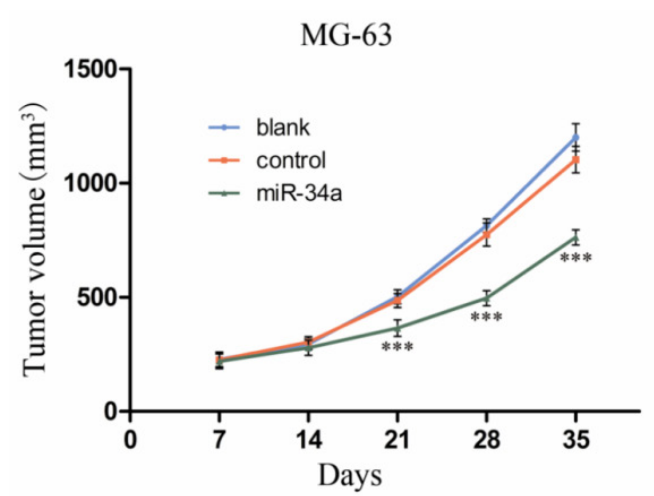

inhibited osteosarcoma growth in vitro and in vivo [19]. A recent report showed that Eag1 expression was negatively regulated by $\mathrm{p} 53$ through p53-miR34-E2F1 pathway in human neuroblastoma cells [20]. Given the tumor suppressor role of miR-34a in osteosarcoma we showed above, we postulate that Eag1 expression may be negatively regulated by miR-34a. Our results showed that endogenous Eag1 protein level in miR-34a group cells was significantly decreased. In contrast, the expression level of Eag1 was increased in miR-34a-2'-O-Me transfected cells (Fig. 5). These results suggest that the tumor suppressor activity of miR-34a is mediated through negative regulation of oncogenic protein Eag1.

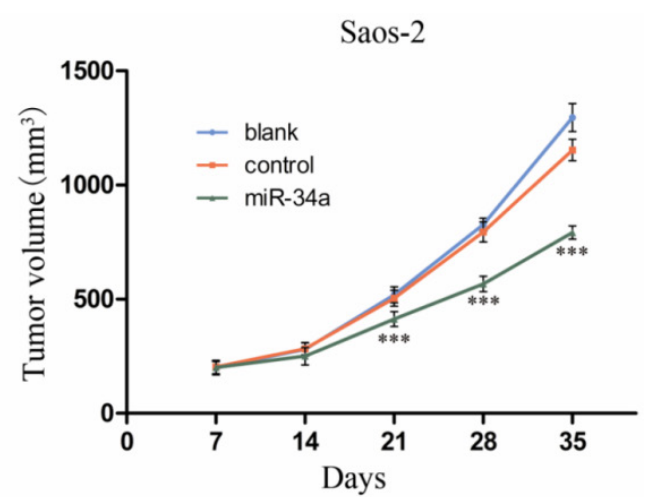

Figure 4. miR-34a inhibits osteosarcoma growth in vivo. The length and width of tumor were measured weekly after inoculation and the volume of tumor was calculated. After 5 weeks, the tumor volume growth curve was drafted. $* * * P<0.00 \mathrm{I}$ vs. control.

A

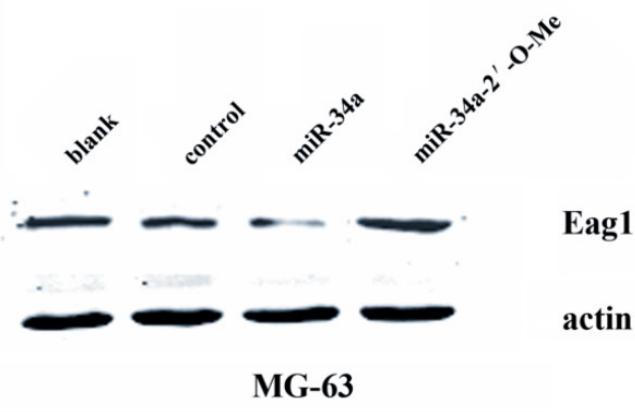

B

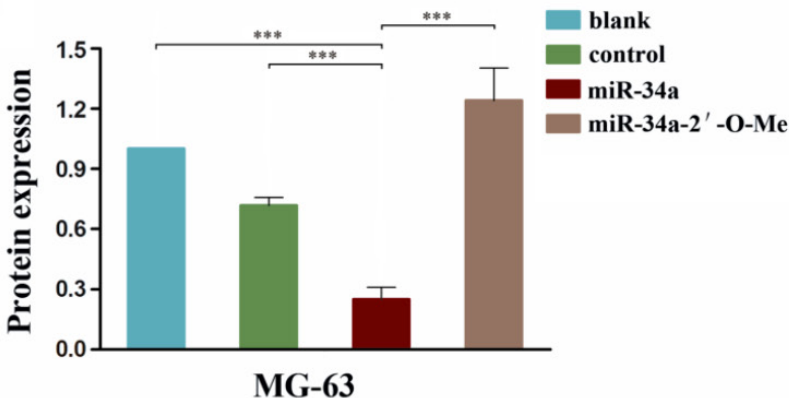

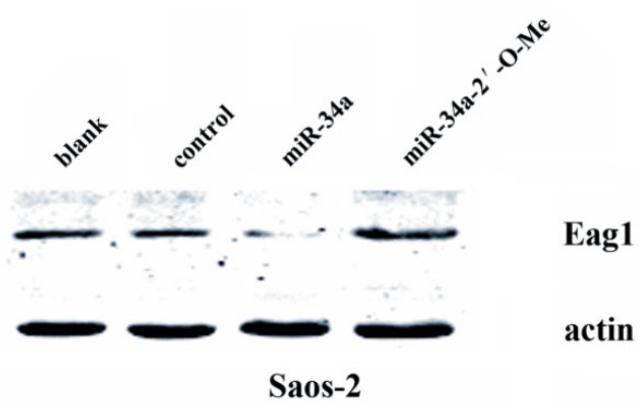

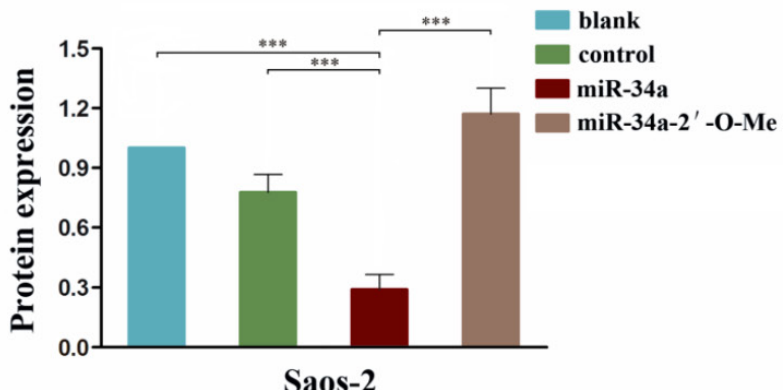

Figure 5. miR-34a regulates Eag I expression. A: Western blot analysis showed that the expression level of Eag I in the miR-34a group was significantly lower than that in the blank group or control group, while the expression level of Eagl was increased in the miR-34a-2'-O-Me group. B: Grey-value analysis of the bolts with actin as the internal reference. The results were expressed as mean \pm SD ( $n=3$ ). $* * *$ $\mathrm{P}<0.001$. 


\section{Discussion}

In recent years, the functional role of $\mathrm{Kv}$ channels in tumor biology has been an area of intense investigation [21]. In particular, Eag1 (Kv10.1, KCNH1) channel attracts much interest due to its close relation to tumor growth, progression and metastasis. Eag1 is a central nervous system (CNS)-localized channel that is overexpressed in several tumor cell lines and more than $75 \%$ of primary solid tumors [22-24]. The suppression of Eag1 expression caused a significant reduction of cancer cell proliferation [25-27]. Moreover, aggressive tumors were induced when cells with ectopic expression of Eag1 were implanted into immune deficient mice [28]. These studies strongly suggest the oncogenic potential of Eag1 [28, 29]. However, the molecular mechanisms responsible for the overexpression of Eag1 in cancer remain elusive.

Recent studies have shown the involvement of miRNAs in tumorigenesis. The miRNAs with increased expression levels in tumors may function as oncogenes by negatively regulating tumor suppressor genes. On the contrary, the miRNAs frequently downregulated in cancer may function as tumor suppressor and inhibit cancer development by downregulating oncogenes [30]. Recent studies have shown that miRNAs funtion as upstream regulators in osteosarcoma growth, suggesting that miRNAs could be a powerful tool for osteosarcoma prevention and therapeutics $[31,32]$.

miRNA-34 family is a direct target of p53, a well-known tumor suppressor that induces apoptosis, cell cycle arrest and senescence [33-35]. In vertebrates, miRNA-34 family has three members: miRNA-34a, miRNA-34b and miRNA-34c. The mature miRNA-34a sequence is located within the second exon of its non-coding host gene, nearly $30 \mathrm{~kb}$ downstream of its first exon, which contains a predicted p53 binding site. Meanwhile, both miRNA-34b and miRNA-34c are located within a single non-coding precursor [36]. miRNA-34a is downregulated in several types of tumors because of inactivating mutations of p53 [37], including osteosarcoma [38]. Cyclin D1, CDK4 and CDK6, E2F3, N-myc, c-Met and Bcl-2 have been reported to be direct targets of miR-34a [39].

In the present study, we found that miR-34a was significantly downregulated in human osteosarcoma compared to normal osteoblasts. Next our in vitro and in vivo studies showed that overexpression of miR-34a could efficiently suppress the growth of osteosarcoma. To further explore the molecular mechanism underlying miR-34a induced inhibition of osteosarcoma growth, we examined the expression of Eag1 and the data showed that overexpression of miR-34a could significantly inhibit the expression of Eag1 while inhibition of miR-34a increased the expression of Eag1. Collectively, these data demonstrate that miR-34a plays an important role in the regulation of osteosarcoma growth and may function as a tumor suppressor through the downregulation of Eag1 expression in osteosarcoma. However, further studies are needed to confirm that Eag1 is a direct target of miR-34a, which will provide new insight into the pathogenesis of osteosarcoma.

\section{Acknowledgment}

This study was supported by Scientific and Technological Innovation Programs of Nanjing military region, China (No. 10MA077).

\section{Competing Interests}

The authors declare that they have no competing interests.

\section{References}

1. Resnick D, Kransdorf MJ. Bone and joint imaging, 3rd ed. Philadelphia: Saunders, 2005

2. Klein MJ, Siegal GP. Osteosarcoma: anatomic and histologic variants. Am J Clin Pathol. 2006; 125(4):555-81.

3. Panizo-Santos A, Sola I, Lozano M, de Alava E, Pardo J. Metastatic osteosarcoma presenting as a small bowel polyp: a case report and review of the literature. Arch Pathol Lab Med. 2000; 124(11):1682-4.

4. Bielack SS, Kempf-Bielack B, Delling G, Exner GU, Flege S, Helmke K, Kotz R, Salzer-Kuntschik M, Werner M, Winkelmann W, Zoubek A, Jürgens H, Winkler K.Prognostic factors in high-grade osteosarcoma of the extremities or trunk: an analysis of 1,702 patients treated on neoadjuvant cooperative osteosarcoma study group protocols. J Clin Oncol. 2002; 20(3):776-90.

5. Eppert K, Wunder JS, Aneliunas V, Kandel R, Andrulis IL. von Willebrand factor expression in osteosarcoma metastasis. Mod. Pathol. 2005; 18(3):388-97.

6. Tan ML, Choong PF, Dass CR. Osteosarcoma: Conventional treatment vs. gene therapy. Cancer Biol Ther. 2009; 8(2):106-17.

7. Ambros V. The functions of animal microRNAs. Nature. 2004; 431(7006):350-5.

8. Bartel DP. MicroRNAs: genomics, biogenesis, mechanism, and function. Cell. 2004; 116(2):281-97.

9. Zamore PD, Haley B. Ribo-gnome: the big world of small RNAs. Science. 2005; 309(5740):1519-24.

10. Lewis BP, Burge CB, Bartel DP. Conserved seed pairing, often flanked by adenosines, indicates that thousands of human genes are microRNA targets. Cell. 2005; 120(1):15-20.

11. Cho WC. OncomiRs: the discovery and progress of microRNAs in cancers. Mol Cancer. 2007; 6:60.

12. Duan $Z$, Choy E, Harmon D, Liu X, Susa M, Mankin H, Hornicek F. MicroRNA-199a-3p is downregulated in human osteosarcoma and regulates cell proliferation and migration. Mol Cancer Ther. 2011; 10(8):1337-45.

13. Ziyan W, Shuhua $Y$, Xiufang W, Xiaoyun L. MicroRNA-21 is involved in osteosarcoma cell invasion and migration. Med Oncol. 2011; 28(4):1469-74

14. Montanini L, Lasagna L, Barili V, Jonstrup SP, Murgia A, Pazzaglia L, Conti A, Novello C, Kjems J, Perris R, Benassi MS. MicroRNA cloning and sequencing in osteosarcoma cell lines: differential role of miR-93. Cell Oncol (Dordr). 2012; 35(1):29-41.

15. Chen C, Ridzon DA, Broomer AJ, Zhou Z, Lee DH, Nguyen JT, Barbisin M, Xu NL, Mahuvakar VR, Andersen MR, Lao KQ, Livak KJ, Guegler KJ. Real-time quantification of microRNAs by stem-loop RT-PCR. Nucleic Acids Res. 2005; 33(20):e179.

16. Gao YS, Mei J, Tong TL, Hu M, Xue HM, Cai XS. Inhibitory effects of VEGF-siRNA mediated by adenovirus on osteosarcoma-bearing nude mice. Cancer Biother Radiopharm. 2009; 24(2):243-7. 
17. de Antonellis P, Medaglia C, Cusanelli E, Andolfo I, Liguori L, De Vita G, Carotenuto M, Bello A, Formiggini F, Galeone A, De Rosa G, Virgilio A, Scognamiglio I, Sciro M, Basso G, Schulte JH, Cinalli G, Iolascon A, Zollo M. MiR-34a targeting of Notch ligand delta-like 1 impairs CD15+/CD133+ tumor-propagating cells and supports neural differentiation in medulloblastoma. PLoS One. 2011; 6(9):e24584.

18. He C, Xiong J, Xu X, Lu W, Liu L, Xiao D, Wang D. Functional elucidation of MiR-34 in osteosarcoma cells and primary tumor samples. Biochem Biophys Res Commun. 2009; 388(1):35-40.

19. Wu J, Wu XY, Zhong DX, Zhai WL, Ding ZQ, Zhou Y. Short Hairpin RNA (shRNA) Ether à go-go 1 (Eag1) Inhibition of Human Osteosarcoma Angiogenesis via VEGF/PI3K/AKT Signaling. Int J Mol Sci. 2012; 13(10):12573-83.

20. Lin H, Li Z, Chen C, Luo X, Xiao J, Dong D, Lu Y, Yang B, Wang Z. Transcriptional and post-transcriptional mechanisms for oncogenic overexpression of ether à go-go $\mathrm{K}^{+}$channel. PLoS ONE. 2011; 6(5):e20362.

21. Pardo LA, Contreras-Jurado C, Zientkowska M, Alves F, Stuhmer W. Role of voltage-gated potassium channels in cancer. J Membr Biol 2005; 205(3):115-24.

22. Camacho J. Ether à go-go potassium channels and cancer. Cancer Lett. 2006; 233(1):1-9.

23. Hemmerlein B, Weseloh RM, Mello de Queiroz F, Knötgen H, Sánchez A, Rubio ME, Martin S, Schliephacke T, Jenke M, Heinz JR, Stühmer W, Pardo LA. Overexpression of Eag1 potassium channels in clinical tumours. Mol Cancer. 2006; 5:41.

24. Wu J, Wu X, Lian K, Lin B, Guo L, Ding Z. Overexpression of potassium channel ether à go-go in human osteosarcoma. Neoplasma 2012; 59(2):207-15.

25. Mello de Queiroz F, Suarez-Kurtz G, Stühmer W, Pardo LA. Ether à go-go potassium channel expression in soft tissue sarcoma patients. Mol Cancer. 2006; 5:42.

26. Weber C, Mello de Queiroz F, Downie BR, Suckow A, Stühmer W, Pardo LA. Silencing the activity and proliferative properties of the human EagI Potassium Channel by RNA Interference. J Biol Chem. 2006; 281(19):13030-7.

27. García-Ferreiro RE, Kerschensteiner D, Major F, Monje F, Stühmer W, Pardo LA. Mechanism of block of hEag1 $\mathrm{K}^{+}$channels by imipramine and astemizole. J Gen Physiol. 2004; 124(4):301-17.

28. Pardo LA, del Camino D, Sánchez A, Alves F, Brüggemann A, Beckh S, Stühmer W. Oncogenic potential of EAG K+ channels. EMBO J. 1999; 18(20):5540-7.

29. Asher V, Sowter H, Shaw R, Bali A, Khan R. Eag and HERG potassium channels as novel therapeutic targets in cancer. World J Surg Oncol 2010; $8: 113$.

30. Zhang B, Pan X, Cobb GP, Anderson TA. microRNAs as oncogenes and tumor suppressors. Dev Biol. 2007; 302(1):1-12.

31. Zhang $\mathrm{H}$, Cai $\mathrm{X}$, Wang $\mathrm{Y}$, Tang $\mathrm{H}$, Tong D, Ji F. microRNA-143, down-regulated in osteosarcoma, promotes apoptosis and suppresses tumorigenicity by targeting Bcl-2. Oncol Rep. 2010; 24(5):1363-9.

32. Liu LH, Li H, Li JP, Zhong H, Zhang HC, Chen J, Xiao T. miR-125b suppresses the proliferation and migration of osteosarcoma cells through down-regulation of STAT3. Biochem Biophys Res Commun. 2011; 416(1-2):31-8

33. Bommer GT, Gerin I, Feng Y, Kaczorowski AJ, Kuick R, Love RE, Zhai Y, Giordano TJ, Qin ZS, Moore BB, MacDougald OA, Cho KR, Fearon ER. p53-mediated activation of miRNA34 candidate tumor-suppressor genes. Curr Biol. 2007; 17(15):1298-307.

34. Hermeking H. p53 enters the microRNA world. Cancer Cell. 2007; 12(5):414-8.

35. Hermeking H. The miR-34 family in cancer and apoptosis. Cell Death Differ. 2010; 17(2):193-9.

36. He L, He X, Lowe SW, Hannon GJ. microRNAs join the p53 network--another piece in the tumour-suppression puzzle. Nat Rev Cancer. 2007; 7(11):819-22.

37. Guessous F, Zhang Y, Kofman A, Catania A, Li Y, Schiff D, Purow B, Abounader R. microRNA-34a is tumor suppressive in brain tumors and glioma stem cells. Cell Cycle. 2010; 9(6):1031-6.

38. Yan K, Gao J, Yang T, Ma Q, Qiu X, Fan Q, Ma B. MicroRNA-34a inhibits the proliferation and metastasis of osteosarcoma cells both in vitro and in vivo. PLoS One. 2012; 7(3):e33778.

39. Liu C, Kelnar K, Liu B, Chen X, Calhoun-Davis T, Li H, Patrawala L, Yan H, Jeter C, Honorio S, Wiggins JF, Bader AG, Fagin R, Brown D, Tang DG. The microRNA miR-34a inhibits prostate cancer stem cells and metastasis by directly repressing CD44. Nat Med. 2011; 17(2):211-5. 